\title{
Reduced Plasma Somatomedin Activity and Costal Cartilage Sulfate Incorporation Activity during Experimental Growth Retardation in the Fetal Rat
}

\author{
F. A. DE PRINS, D. J. HILL, M. FEKETE, D. J. ROBSEN, N. R. J. FIELLER, \\ F. A. VAN ASSCHE, AND R. D. G. MILNER \\ The Unit for the Study of Reproduction, Department Ontwikkelingsbiologie, Katholicke Universiteit, Leuven, \\ Belgium and Departments of Paediatrics [D.J.H., M.F., R.D.G.M.] and Probability and Statistics [D.J.R., \\ N.R.J.F.], University of Sheffield, Sheffield S10, United Kingdom
}

\begin{abstract}
In this study, the experimental model of Wigglesworth was used to limit the maternal blood supply to the rat fetus and induce intrauterine growth retardation. The associated changes in plasma somatomedin activity, insulin, glucose, and cartilage metabolic activity are reported. The mean body weight ( \pm SEM) of 108 fetuses in ligated uterine horns was significantly lower than that of 146 control fetuses (ligated, $2820 \pm 50 \mathrm{mg}$; control, 3180 $\pm 50 \mathrm{mg} ; p<0.001$, as was mean nose-tail tip length (ligated, $55.6 \pm 0.4 \mathrm{~mm}$; control, $59.4 \pm 0.3 \mathrm{~mm} ; p<$ 0.001 ) and mean liver weight (ligated, $222 \pm 5 \mathrm{mg}$; control, $274 \pm 5 \mathrm{mg} ; p<0.001)$. The uptake of $\left[{ }^{35}\right.$ S]sulfate by fetal costal cartilage in basal culture medium was significantly lower in growth-retarded fetuses than in controls. Plasma somatomedin activity measured by fetal rat cartilage bioassay was significantly lower in growth-retarded than in control fetuses $(p<0.001)$. The growth-retarded fetuses were relatively hypoinsulinemic and hypoglycemic compared to control animals. These studies suggest that nutrient supply may become a limiting factor in the release of insulin and the circulating levels of somatomedin activity in the rat fetus, and hence in its growth. (Pediatr Res 18:1100-1104)
\end{abstract}

\section{Abbreviation}

MSA, multiplication-stimulating activity

The growth hormone-dependent peptide growth factors, the somatomedins, have a major role in the growth and development of skeletal and somatic tissues in postnatal life (1). Somatomedins also are present in the fetus and a positive correlation between circulating levels and fetal body size led us and others to hypothesize that somatomedins providean important anabolic stimulus to development in utero (2-5). However, the factors controlling circulating levels of somatomedins in the fetus are not understood. Growth hormone does not appear to be important since decapitation of the fetal rabbit and hypophysectomy of the lamb in utero did not lower somatomedin bio- and radioreceptor

Received October 25, 1983; accepted April 20, 1984.

Correspondence may be addressed to Dr. D. J. Hill, Department of Paediatrics, Clinical Sciences Centre, Northern General Hospital, Sheffield S5 7AU United Kingdom. activity, and did not seriously retard body growth $(6,7)$. Nutritional composition and availability influenced postnatal somatomedin release, over-riding the actions of growth hormone, and nutrient availability could regulate fetal growth through somatomedin action (8). However, it is not possible to investigate nutrition without considering the release and action of insulin which also has been postulated to be a major anabolic hormone in utero (9).

In this study, the experimental model of Wigglesworth (10) was used to limit the maternal blood supply to the rat fetus. This was reported to result in a relative intrauterine growth retardation accompanied by fetal hypoglycemia and hypoinsulinemia, but the outcome in terms of fetal survival and morphometry has been extremely variable (10-12). The purpose of our experiments was to perform a detailed statistical analysis of the validity of the model and to investigate the relationship between circulating levels of somatomedin bioactivity, insulin and glucose, endogenous cartilage metabolic activity, and body and organ size during experimental fetal growth retardation.

\section{MATERIALS AND METHODS}

Animals. Pregnant Wistar rats of approximately $250 \mathrm{~g}$ weight were taken from the departmental colony and mated overnight. The day of mating was confirmed by the appearance of the vaginal plug and was designated day 1 of gestation. Animals had free access to food and water. On day 17, a laparotomy was performed under ether anesthesia via a midline incision. The uterine horn containing the larger number of fetuses was selected, and the uterine artery and vein on that side were occluded by ligation at the cervix. The other uterine horn was left as a control and the maternal incision closed. On the morning of day 21 the rats were killed painlessly and all fetuses were delivered immediately by cesarian section. As each fetus was exposed, a deep incision was made in the axillary region and blood was collected on ice while the placenta and umbilicus were still intact. The latter point is of importance since blood glucose and insulin values can alter rapidly in the rat fetus especially following severance of the umbilical cord (13). Blood from all animals within a single uterine horn, either ligated or control, was pooled before the centrifugation and separation of plasma which was stored at $-20^{\circ} \mathrm{C}$. After noting the position of each fetus within the uterus, they were weighed to an accuracy of $1 \mathrm{mg}$ and the nose-tail length was measured by ruler to the nearest millimeter. Liver weight was recorded to an accuracy of $1 \mathrm{mg}$ before the removal of costal cartilage.

Cartilage incubation. Costal cartilage was dissected from every 
fetus within a ligated uterine horn, and from an equivalent number of fetuses from the nonligated horn at comparable implantation positions. When the control fetuses were fewer all fetuses within the litter were used. Cartilage incubations were performed in a Krebs phosphosaline buffer enriched with amino acids (14), and supplemented with penicillin (100 microunits/ $\mathrm{ml})$ and streptomycin $(100 \mu \mathrm{g} / \mathrm{ml})$. Medium was sterilized by passage through a Millipore filter $(0.45 \mu \mathrm{m})$ before use. Cartilage was incubated in basal culture medium containing $\left[{ }^{35} \mathrm{~S}\right]$ sulfate (Amersham International, Bucks, England) with and without a supplement of $10 \%(\mathrm{v} / \mathrm{v})$ normal adult rat plasma. This provided an indication of the previous metabolic activity of the tissue in vivo and the extent to which it could be further stimulated in vitro (14). Results are expressed as the mean of duplicate incubations in counts/min per mg weight cartilage.

Hormone assay. Fetal rat plasma somatomedin activity was measured by the fetal rat costal cartilage bioassay system described earlier $(14,15)$. Pooled costal cartilage was taken from the control fetuses in the nonligated uterine horn. The assay utilizes the incorporation of $\left[{ }^{35} \mathrm{~S}\right]$ sulfate in vitro and results were calculated as relative potencies compared to standard adult rat plasma of defined potency $1.0 \mathrm{unit} / \mathrm{ml}$. Insulin levels in the fetal rat were measured by radioimmunoassay as described previously (15). All samples were included within a single assay. Blood glucose was measured by a glucose oxidase technique (16).

\section{RESULTS}

Technical success. Of 41 pregnant rats submitted to surgery, 37 animals retained one or more fetuses within the ligated uterine horn. Of these, six rats retained a single fetus, 10 retained two fetuses, 11 retained three fetuses, four retained four fetuses, four retained 5 fetuses, and two retained six fetuses. The mean $( \pm$ SEM) number of surviving fetuses per litter in the ligated and nonligated horns was $2.9 \pm 0.2$ (range, $1-6$ ) and $3.9 \pm 0.2$ (range, 1-8), respectively. In three animals, all experimental fetuses were resorbed and in one rat extensive anastomosis of blood vessels occurred around the ligation. This animal was excluded from the experiment. Of 217 fetuses present at surgery in the ligated horns, $109(49 \%)$ had been resorbed by day 21 , while of 148 fetuses within the control uterine horns only $2(1 \%)$ were resorbed. Resorption and intrauterine growth retardation were not limited to sites close to the ligature.

Body size and cartilage metabolic activity. The mean body weight $( \pm$ SEM) of 108 fetuses in the ligated uterine horn was significantly lower than that of 146 control fetuses when assessed by $t$ test for mean values (ligated, $2820 \pm 50 \mathrm{mg}$; control, 3180 $\pm 50 \mathrm{mg} ; p<0.001$ ), as was nose-tail tip length (ligated, $55.6 \pm$ $0.4 \mathrm{~mm}$; control, $59.4 \pm 0.3 \mathrm{~mm} ; p<0.001$ ) and liver weight (ligated, $222 \pm 5 \mathrm{mg}$; control, $274 \pm 5 \mathrm{mg} ; p<0.001$ ). Liver weight expressed as a percentage of total body weight was significantly lower in fetuses from the ligated horn than in control animals (ligated, $7.96 \pm 0.11 \%$, control, $8.91 \pm 0.09 \%, p<$ $0.001)$. The findings were confirmed by rigorous multivariate analysis of variance taking account of the between and within litter variation and the implantation site of the fetus within the uterus (Table 1). Fetuses were numbered chronologically within each uterine horn, the first animal being that nearest the ovary and the last that nearest the cervix. When compared by paired analysis, a significant comparative growth retardation existed between fetuses in the ligated and control horns in positions 1 to 3 , and was most pronounced in position 3 as seen by the $t$ values and a percentage reduction in body weight of $18 \%$. However, within each uterine horn, for both ligation and control, mean body weight did not differ with the site of implantation and the mean weight of fetuses did not alter with litter size.

The mean $( \pm \mathrm{SD})$ uptake of $\left.{ }^{35} \mathrm{~S}\right]$ sulfate by costal cartilage in basal culture medium was significantly lower in fetuses from the ligated horn than in controls (ligated, $1808 \pm 686 \mathrm{cpm} / \mathrm{mg}$; control, $2242 \pm 908 ; p<0.005$ by paried $t$ test for 86 pairs of animals). In the presence of normal rat plasma $(10 \%, \mathrm{v} / \mathrm{v})$, the incorporation of isotope was stimulated to a similar extent above basal levels in cartilage from both groups of animals, and the resulting incorporation did not differ significantly between groups (ligated, $8905 \pm 3244$; control, $9280 \pm 3828$ ). Isotope uptake in basal culture medium showed positive correlation with body weight, length, and liver weight when test and control fetuses were considered together but this was dependent on the site of implantation within the uterus, being significant at positions $3(r=0.50$ or better; $n=54 ; p<0.05)$ and $4(r=0.70$ or better; $n=12 ; p<0.05$ ) only. This was possibly due to the relative growth retardation being greatest in these positions leading to a wide distribution of parameters of size.

Plasma somatomedin activity. Somatomedin activity (mean \pm SD), measured by fetal rat cartilage assay, in pooled plasma from all fetuses in the ligated uterine horn of each litter was significantly lower than that found in pooled plasma from all fetuses in the control horn (ligated, $0.62 \pm 0.22 \mathrm{unit} / \mathrm{ml}$; control, 0.85 $\pm 0.28 \mathrm{unit} / \mathrm{ml} ; p<0.001$ by paired $t$ test for 31 litters). When all fetuses were considered, the levels of somatomedin activity in pooled plasma from animals in each horn correlated positively with body weight ( $r=0.37 ; n=65 ; p=0.01)$, body length (Fig. $1)$ and liver weight $(r=0.41 ; n=65 ; p<0.001)$. In these calculations, the mean uterine horn values for parameters of body size were employed for each group. For fetuses from the ligated horn alone, significant correlations were present with body weight $(r=0.48 ; n=34)$, length $(r=0.45 ; n=34)$ and liver weight $(r=0.44 ; n=34 ; p<0.01)$, but no significant correlations existed for control animals alone with any parameter $(r=0.12-0.14 ; p<0.1)$. No significant correlation existed between plasma levels of insulin and somatomedin $(p<0.1)$ for ligated or control animals considered either separately or together $(n=46)$.

Insulin and glucose levels. Insulin and glucose were measured in pooled plasma from all fetuses in either the ligated or control horns for each litter where sufficient plasma was available. $\mathrm{Fe}$ tuses from the ligated uterine horn were relatively hypoinsuli-

Table 1. Mean body weight ( \pm SEM), significance level, and t values (in parentheses) from a paired analysis between fetuses present in the ligated and control uterine horn for body weight $(W)$, length $(L)$, liver weight $(L W)$, and basal (B) and plasma-stimulated (S) uptake of $\left[^{35} S J\right.$ sulfate by cartilage in vitro, with regard to the position of the fetuses in the uterus*

\begin{tabular}{|c|c|c|c|c|c|c|c|c|}
\hline \multirow{2}{*}{$\begin{array}{l}\text { Position } \\
\text { in uterus }\end{array}$} & \multirow[b]{2}{*}{$n$} & \multicolumn{2}{|c|}{$\begin{array}{l}\text { Body weight } \\
\text { (mg) }\end{array}$} & \multicolumn{5}{|c|}{ Significance level $(p)$} \\
\hline & & Ligated & Control & W & $\mathrm{L}$ & LW & B & S \\
\hline 2. & 29 & $2875 \pm 96$ & $3263 \pm 105$ & $\begin{array}{l}<0.001 \\
(-4.68)\end{array}$ & $\begin{array}{l}<0.001 \\
(-4.81)\end{array}$ & $\begin{array}{r}<0.001 \\
(-4.98)\end{array}$ & $\begin{array}{c}0.05 \\
(-2.13)\end{array}$ & $\begin{array}{c}\text { NS } \\
(-1.14)\end{array}$ \\
\hline 3. & 18 & $2747 \pm 128$ & $3340 \pm 162$ & $\begin{array}{l}<0.001 \\
(-7.83)\end{array}$ & $\begin{array}{l}<0.001 \\
(-7.46)\end{array}$ & $\begin{array}{r}<0.001 \\
(-10.06)\end{array}$ & $\begin{array}{l}<0.002 \\
(-3.71)\end{array}$ & $\begin{array}{c}\text { NS } \\
(-0.86)\end{array}$ \\
\hline
\end{tabular}

* Values were obtained by analysis of variance. NS, not significant. Position 1 is nearest the ovary. 


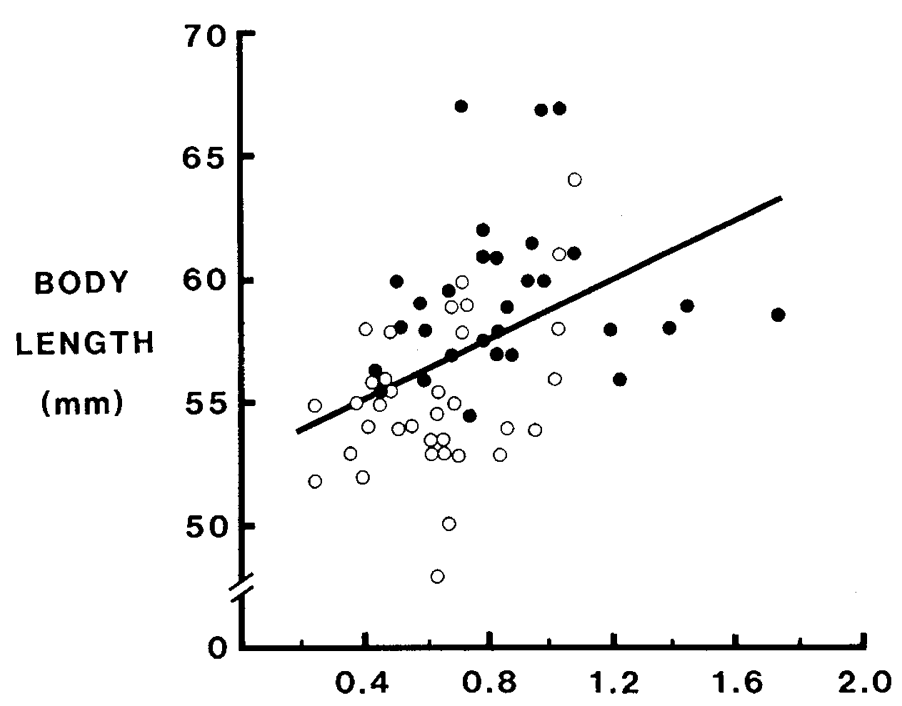

SOMATOMEDIN ACTIVITY $(\mathrm{U} / \mathrm{mI})$

Fig. 1. Somatomedin activity in pooled plasma from rat fetuses in each ligated $(O)$ and control $(\bullet)$ uterine horn compared to the mean body length of fetuses within that horn $(r=0.44 ; n=65 ; p<0.001)$.

nemic (ligated, $189 \pm 117$ units/ml, mean \pm SD; control, $286 \pm$ 191 microunits $/ \mathrm{ml} ; p<0.025$, by paired $t$ test for 24 litters), and hypoglycemic (ligated, $1.5 \pm 0.9 \mathrm{mM} /$ liter; control, $3.2 \pm 2.4$ $\mathrm{mM} /$ liter; $p<0.001$ by paired $t$ test for 23 litters) compared to control animals. Plasma insulin values showed no significant correlation with either fetal body weight or length, the measurements of size being calculated as mean values for either ligated or control horns. However, highly significant positive correlations $(p<0.001)$ existed between plasma glucose levels and mean litter values for body weight $(r=0.82)$ and body length $(r=$ $0.75)$ when both fetal groups were considered either together $(n$ $=46)$ or separately $(n=23)$. Plasma somatomedin activity also was positively related to plasma glucose levels when both parameters were logarithmically transformed $(r=0.41 ; n=44 ; p<$ $0.01)$. No significant correlation was found between plasma levels of glucose and insulin and the insulin/glucose ratio did not significantly differ between plasma from fetuses in ligated and control horns (ligated, $175 \pm 58$; control, $135 \pm 43$; mean \pm SEM).

\section{DISCUSSION}

Several authors have described the relative fetal growth retardation resulting from ligation of the uterine artery and vein in one uterine horn of the pregnant rat $(10-12,17)$ but the distribution of fetal size described by Wigglesworth has been difficult to reproduce. A comprehensive analysis of the model with reference to the site of implantation within the uterus and the considerable between-litter variation has been lacking. Wigglesworth concluded that where several fetuses remained in the ligated uterus at least 4 days after surgery there was a graded decrease in size between the fetuses at the ovarian and cervical extremes (10). At the ovarian end of the uterus fetuses were of comparable size to those in the control horn while at the cervical end fetuses were commonly dead or resorbed.

Our analysis differs from this account in several ways. Firstly, a statistically significant relative growth retardation was found between fetuses in ligated and control horns at the implantation site nearest to the ovary, although this was more pronounced at the second and third furthest sites from the ovary compared to the corresponding control fetus. Secondly, fetal resorption was found at every implantation site in the uterus and a live fetus could be present between two resorbed animals. Although there was a general decrease in fetal body size in the ligated horn from ovary to cervix, this was not statistically significant. We therefore conclude that the fetal growth retardation encountered here was a more general phenomenon throughout the ligated uterus than that described previously, and that when using this experimental model to identify changes in circulating fetal hormone levels it is acceptable to take a pooled sample of blood from all surviving, fetuses within a uterine horn.

Assessment of skeletal growth by the measurement of nosetail tip length showed that skeletal tissues were relatively less affected than body weight, but the incorporation of $\left[{ }^{35} \mathrm{~S}\right]$ sulfate in vitro by cartilage from growth-retarded fetuses was significantly lower than that in control animals. This is unlikely to represent a general decrease in tissue anabolism in fetuses from the ligated horn since isotope uptake was enhanced in cartilage from both growth-retarded and control animals when exposed to a plasma challenge, demonstrating that the cellular mechanisms of hormone action remained intact. The precise origin of growth retardation in the Wigglesworth model is not known but could involve placental ischemia, a reduced transplacental passage of nutrients, or a reduced oxygen availability to the fetus.

Bioassayable somatomedin activity was reduced in fetuses from the ligated uterine horn and was positively correlated to parameters of body size. The bioassay used utilizes fetal rat cartilage and detects the sulfation factor activity present in fetal plasma. This was greater than that detectable in a bioassay based on postnatal porcine cartilage suggesting that additional sulfation factor activity was present in the rat fetus to which postnatal cartilage was refractory (14). Fetal rat cartilage also detected substantially more sulfation factor activity in plasma from hypophysectomized rats compared to normal rat plasma than did postnatal cartilage, further suggesting that the spectrum of tissue sensitivity to growth factors differs between fetal and postnatal life. An analogous report by Sara and Hall (3) found that a radioreceptor assay using human fetal brain cell membranes detected somatomedin activity in human fetal serum not measurable using a conventional radioimmunoassay for somatomedin A. Purified peptide growth factors including the two somatomedins, somatomedin-C and MSA II, promoted radiolabeled thymidine incorporation by fetal rat cartilage in vitro $(18,19)$. MSA II promoted the uptake of radioactive sulfate in this system but somatomedin-C was without effect.

Since the physiologically important somatomedin peptides in the fetal rat have not yet been characterized and identified, we have maintained that a bioassay appropriate for species and gestational age is at least as relevant as more specific assays for particular somatomedins purified from adult serum or tissues. Using the latter, radioimmunoassayable serum insulin-like growth factor I (somatomedin-C) and somatomedin A were reported to be lower than adult values in the fetal rat $(20,21)$ while MSA measured by radioreceptor or immunoassay was many times greater in the fetal and neonatal rat than in later life $(20,22)$. When detected by a postnatal rat cartilage bioassay, somatomedin activity was considerably lower than adult levels in fetal rat serum (23). While the fetal rat cartilage bioassay may detect so far uncharacterized fetal growth factors, it does provide a sensitive indicator of at least one purified somatomedin, MSA II, found by specific assay to be elevated in the fetal rat circulation. The positive correlation between somatomedin bioactivity and fetal size suggests that its measurement is of biological relevance.

During acute postnatal malnutrition, inhibiting factors were detected in serum which interfered with the action of somatomedins in biological assay systems (8). Since in the fetal cartilage assay-parallel dose responses were always obtained between test plasma from growth-retarded fetuses and the standard rat plasma, there was no evidence for the presence of inhibitory factors to cartilage sulfation. The present results support those of Foley et al. (24) who found somatomedin levels in the cord blood of the human growth-retarded infant to be lower than those of normally grown infants.

While the present study establishes a reduced somatomedin 
activity and cartilage metabolic activity associated with fetal growth retardation in the rat, it does not identify the mechanisms responsible for this observation. It must be considered whether the growth retardation and associated endocrine changes represent a delay of fetal maturation. The endocrinology may therefore be appropriate for the development of the fetus. This is supported by the finding of Kollee et al. (25) that there was a delay in the development of gluconeogenic enzymes in growthretarded rats in the same experimental model. However comparison with our own published data for the growth of the fetal Wistar rat (14) shows that, in terms of body weight and length, fetal development was delayed by less than 2 days gestation. Between days 19 and 21 of gestation, there was no alteration in cartilage sulfate uptake in vitro or in bioassayable somatomedin activity, measured by either fetal rat or postnatal porcine cartilage assay, in the normal rat fetus. The reduced circulating somatomedin activity in growth-retarded fetuses may therefore reflect an adaptive change.

The ability to produce somatomedin was shown to be a property of many fetal tissues (26) but the liver, because of its size, is likely to be the major source of somatomedin activity in the circulation. Somatomedins, like insulin and growth hormone, do not cross the placenta from mother to fetus (27). The mechanism of action of somatomedins in fetal life is unsure. A widespread production of somatomedins by fetal tissues may represent a largely paracrine system of growth control in which case those peptides contributing to plasma somatomedin activity may only be an indirect indicator of tissue anabolism. A reduced circulating somatomedin activity during intrauterine growth retardation could result from a direct influence of nutrient availability on somatomedin release throughout the body. Alternatively, the association between nutrition and somatomedins could be mediated via the endocrine system.

Growth hormone has a major role in the control of somatomedin production after birth but is thought to be unnecessary for the maintenance of growth and somatomedin activity in fetal life $(6,7)$. Although the limited availability of plasma precluded the measurement of fetal growth hormone in this study, it has previously been reported that circulating levels were raised in growth-retarded rat fetuses compared to control animals in the Wigglesworth model (28).

Although insulin is often postulated to act as a growth-promoting hormone in fetal life, there is little evidence that it is directly mitogenic at physiological concentrations. Insulin had no direct action at physiological concentrations on the uptake of either $\left[{ }^{3} \mathrm{H}\right]$ thymidine or $\left[{ }^{35} \mathrm{~S}\right]$ sulfate by fetal rat costal cartilage in vitro $(2,18)$. The administration of pharmacological concentrations of insulin to the fetal rat and monkey led to enhanced body growth $(29,30)$, but this may have been mediated by an increase in circulating somatomedin since somatomedin activity was enhanced in the fetal rabbit and pig following treatment with insulin in utero $(31,32)$. In the postnatal rat, insulin was shown to stimulate somatomedin production directly from liver during perfusion and tissue slice incubation $(33,34)$. The induction of hyperglycemia in the fetal rat in late gestation resulted in enhanced levels of circulating insulin and increased body weight (35) and raised circulating somatomedin activity (36).

Positive relationships therefore exist between fetal body size and the levels of insulin and somatomedin in the blood as seen from the significant correlation between body weight or length and somatomedin activity in the present experiments, and our previous findings that immunoassayable levels of insulin $C$ peptide in amniotic fluid were reduced compared to control animals and showed positive correlation with body weight in the Wigglesworth model (37). These studies suggest that nutrient supply may become a limiting factor in the release of both insulin and somatomedin in the rat fetus, and hence in its growth.

Acknowledgments. When these studies were performed, D. J. Hill held the J. G. Graves Research Fellowship of the University of Sheffield. We are grateful to Mr. J. Milnes and Mrs. R. Davies for technical assistance. The bioassay statistics program used in the measurement of somatomedin activity was developed by Dr. N. R. J. Fieller, Department of Probability and Statistics, University of Sheffield. The program uses the two numerical algorithm group library routines $\mathrm{S} 14 \mathrm{AAF}$ and DO1 AGF.

\section{REFERENCES}

1. Phillips LS, Vassilopoulou-Sellin R 1980 Somatomedins. N Engl J Med 302:371

2. Hill DJ, Milner RDG 1981 Somatomedins and fetal growth. In: Elliott K, Whelan J (eds) The Fetus and Independent Life. pp 124-138, Ciba Foundation Symposium No. 86, London

3. Sara VR, Hall K, Rodeck CH, Wetterberg L 1981 Human embryonic somatomedin. Proc Natl Acad Sci USA. 78:3175

4. Ashton IK. Vesey J 1978 Somatomedin activity in human cord plasma and relationship to birth size, insulin growth hormone and prolactin. Early Human Dev 2:115

5. Kastrup KW, Anderson HJ, Lebech $P 1978$ Somatomedin in newborns and the relationship to human chorionic somatotropin and fetal growth. Acta Paediatr Scand 67:757

6. Hill DJ, Davidson P. Milner RDG 1979 Retention of plasma somatomedin activity in the foetal rabbit following decapitation in utero. $J$ Endocrinol $81: 93$

7. Brinsmead MW, Liggins GC 1979 Serum somatomedin activity after hypophysectomy and during parturition in fetal lambs. Endocrinology 105:297

8. Phillips LS, Unterman TG 1984 Somatomedin activity in disorders of nutrition and metabolism. Clin Endocrinol Metab 13:145

9. Girard JR, Rieutort M, Kervran A. Jost A 1976 Hormonal control of fetal growth with particular reference to insulin and growth hormone. In: Tooth G, Bratteby LE (eds) Perinatal Medicine. Alquist \& Wiksell, Stockholm, p 197

10. Wigglesworth JS 1964 Experimental growth retardation in the foetal rat. J Pathol Bacteriol 88:1

11. De Prins FA, Van Assche FA 1982 Intrauterine growth retardation and development of endocrine pancreas in the experimental rat. Biol Neonate $41: 16$

12. Girard JR, Kervran A, Soufflet E, Assan R 1974 Factors affecting the secretion of insulin and glucagen by the rat fetus. Diabetes $23: 310$

13. Sodoyez-Goffaux FR, Sodoyez JC, De Vos CJ 1979 Insulin secretion and metabolism during the perinatal period in the rat. J Clin Invest 63:1095

14. Hill DJ, Andrews SJ, Milner RDG 1981 Cartilage response to plasma and plasma somatomedin activity in rats related to growth before and after birth. J Endocrinol 90:133

15. Hill DJ, Sheffrin RA, Milner RDG 1982 Raised plasma somatomedin activity and cartilage metabolic activity $\left({ }^{35} \mathrm{~S}\right.$ sulphate uptake in vitro) in the fetus of the mildly diabetic pregnant rat. Diabetologia 23:270

16. Trinder $P 1969$ Determination of blood glucose using an oxidase-peroxidase system with a non-carcinogenic chromogen. J Clin Pathol 22:158

17. Roux JM, Tordet-Caridroit C. Chanel C 1970 Studies on experimental hypertrophy in the rat. Chemical composition of the total body and some organs in the rat fetus. Biol Neonate 75:342

18. Hill DJ, Holder AT, Seid J, Preece MA, Tomlinson S, Milner RDG 1983 Increased thymidine incorporation into fetal rat cartlage in vitro in the presence of human somatomedin, epidermal growth factor and other growth factors. J Endocrinol 96:489

19. Hill DJ, Milner RDG 1984 Platelet-derived growth factor, multiplicationstimulating activity II (MSA II) but not MSA III-2 stimulate $\left({ }^{3} \mathrm{H}\right)$ thymidine and $\left({ }^{35} \mathrm{~S}\right)$ sulphate incorporation by fetal rat costal cartilage in vitro. $\mathrm{J}$ Endocrinol, in press

20. Daughaday WH, Parker KA; Borowsky S, Trevedi B, Kapadia M 1982 Measurement of somatomedin-related peptides in fetal, neonatal and maternal rat serum by insulin-like growth factor (IGF)I radioimmunoassay, IGFII radioreceptor assay (RRA) and multiplication-stimulating activity RRA after acid-ethanol extraction. Endocrinology 110:575

21. Sara VR, Hall K, Lins P, Fryklund L 1980 Serum levels of immunoreactive somatomedin $\mathrm{A}$ in the rat: some developmental aspects. Endocrinology 107:622

22. Moses AC. Nissley SP, Short PA, Rechler MM, White RM, Knight AB, Higa OZ 1980 Increased levels of multiplication-stimulating activity, an insulinlike growth factor, in fetal rat serum. Proc Natl Acad Sci USA 77:3649

23. Stuart MC, Lazarus L. Moore SS, Smythe GA 1976 Somatomedin production in the neonatal rat. Horm Metab Res 8:442

24. Foley TP, Philip R. Perricelli A, Miller A 1980 Low somatomedin activity in cord serum from infants with intrauterine growth retardation. J Paediatr 96:605

25. Kollee LA, Monnens LA, Tri Bels JM, Veerkamp JH, Janssen AJ, Van HaardHustings H 1979 Glucogenic key enzymes in normal and intrauterine growth-retarded newborn rats. Early Human Dev 3:295

26. D'Ercole AJ, Applewhite GT, Underwood LE 1980 Evidence that somatomedin is synthesized by multiple tissues in the fetus. Dev Biol 75:315

27. Underwood LE, D'Ercole AJ 1984 Insulin and insulin-like growth factors/ somatomedins in fetal and neonatal development. Clin Endocrinol Metab 13:69

28. Girard JR, Chanel C, Kervran A. Tordet-Cardidroit C, Assan R 1976 Studies 
on experimental hypotrophy in the rat. III. Plasma insulin and glucagon. Biol Neonate 29:262

29. Angervall L, Karlsson K. Martinsson A 1981 Effects on rat fetuses of intrauterine injections of insulin. Diabetologia 20:558

30. Susa JB, McCormick KL, Widness JA, Singer DB, Oh W, Adamsons K Schwartz R 1979 Chronic hyperinsulinaemia in the fetal rhesus monkey. Effects on fetal growth and composition diabetes. Diabetes 28:1058

31. Hill DJ. Milner RDG 1980 Increased somatomedin and cartilage metabolic activity in rabbit fetuses injected with insulin in utero. Diabetologia 19:143

32. Spencer GSG, Hill DJ, Garsson GJ, McDonald AA, Colenbrander B 1983 Somatomedin activity and growth hormone levels in body fluids of the fetal pig: effect of chronic hyperinsulinaemia. J Endocrinol 96:107

33. Daughaday WH, Philips LS, Mueller MC 1976 The effects of insulin and growth hormone on the release of somatomedin by the isolated rat liver. Endocrinology 98:1214

34. Binoux M. Lassarde C. Hardovin N 1982 Somatomedin production by rat liver in organ culture. III. Studies on the release of insulin-like growth factor and its carrier protein measured by radioligand assays. Effects of growth hormone, insulin and cortisol. Acta Endocrinol 99:422

35. Ktorza A, Nurjhan N, Girard JR, Picon L 1983 Hyperglycaemia induced by glucose infusion in the unrestrained pregnant rat: effect on body weight and lipid synthesis in post-mature fetuses. Diabetologia 24:128

36. Heinze E, Nguyan Thi C, Vetter U. Fussganger RD 1982 Interrelationship of insulin and somatomedin activity in fetal rats. Biol Neonate 41:240

37. De Prins FA, Van Assche FA, Milner RDG 1983 C-peptide levels in amniotic fluid in experimental fetal growth retardation. Biol Neonate 43:181

\title{
Postheparin Plasma Lipoprotein and Hepatic Lipases in Preterm Neonates
}

\author{
LIISA ROVAMO, ESKO A. NIKKILÄ, MARJA RIITTA TASKINEN, AND KARI O. RAIVIO \\ Children's Hospital and Third Department of Medicine, University of Helsinki, Helsinki, Finland
}

\begin{abstract}
Postheparin plasma lipoprotein lipase and hepatic lipase activities of 11 preterm infants aged 1 to 4 days were measured $15 \mathrm{~min}$ after a heparin bolus of 100 IU/kg and during an exchange transfusion performed with fresh heparinized blood. Each infant had a birth weight (range, 1210-3490 g) appropriate for gestational age (range, 28-36 (wk). Eight of the infants (group 1) were in good clinical condition while three (group 2) suffered from septic shock. After the heparin bolus and during the exchange transfusion, lipoprotein and hepatic lipase activities in group 1 were higher than in term infants. In group 2 , both lipase activities were extremely low after the heparin bolus but increased approaching the activities of group 1 during the exchange transfusion. Clearance of fat from the circulation is slower in preterm than term infants. This has been attributed to low lipoprotein lipase activity. Our results, however, indicate that lipoprotein lipase is not the reason for slow clearance of fat from the circulation in preterm infants except in septic shock. (Pediatr Res 18:1104-1107, 1984)
\end{abstract}

Abbreviation

FFA, free fatty acids

Postheparin plasma lipolytic activity has been used as a measure of lipoprotein lipase activity in newborns $(3,7,20)$. In very

Received December 20, 1983; accepted April 23, 1984.

Requests for reprints should be addressed to Dr. Liisa Rovamo, The Children's Hospital, University of Helsinki. Stenbäckinkatu 11, SF-00290 Helsinki 29, Finland.

This work was supported by the Foundation for Pediatric Research, Hilma and Heikki Honkanen's Foundation, Foundation of Nutritional Research. Finnish Academy, Finnish Foundation for Culture. Sigrid Juselius Foundation, and Huhtamäki Oy, Leiras Pharmaceuticals. low birth weight infants, postheparin plasma lipolytic activity is low $(3,20)$, and fat tolerance tests suggest a slow disposal of lipids infused $(1,4,14,17)$. Therefore, it has been assumed that lipoprotein lipase activity is low in preterm infants $(1,3,17,20)$.

However, postheparin plasma lipolytic activity also contains hepatic lipase activity, whose function in triglyceride metabolism has not been established $(6,12,18)$. In term infants, hepatic lipase activity is about three times the lipoprotein lipase activity, and the two lipase activities can vary independently (16). Thus, postheparin plasma lipolytic activity seems to be unsuitable for the evaluation of lipoprotein lipase activity.

We now report specific postheparin plasma lipoprotein and hepatic lipase activities of 11 preterm infants, measured in connection with an exchange transfusion performed because of hyperbilirubinemia, blood group incompatibility, or septicemia.

\section{MATERIALS AND METHODS}

Patients. We studied 11 infants, four girls and seven boys. Nine mothers were healthy. One mother had hypertension because of glomerulonephritis and was treated with clonidine and dihydralazine during the 3 wk preceding delivery. Another mother had idiopathic thrombocytopenia; she received prednisolone during the whole pregnancy.

Six mothers had premature rupture of membranes between 0.5 and 14 days before delivery. Four infants were delivered by cesarean section, the others through vaginal route.

All infants were preterm and of appropriate weight for gestational age. On the basis of clinical findings we divided the infants into two groups. Group 1 consisted of eight infants who were not severely ill. Group 2 consisted of three infants who suffered from septic shock.

Group 1. The mean gestational age was 33.5 wk (range, 2836). The mean birth weight was $2244 \mathrm{~g}$ (range, 1210-3490). Two infants had Apgar scores less than seven at the age of 1 or $5 \mathrm{~min}$. The infants were fed with breast milk; five of them received glucose intravenously too. At the time of the exchange transfusion, the postnatal ages ranged from 4 to $43 \mathrm{~h}$. 